\title{
Markets, infrastructures and infrastructuring markets
}

\author{
Luis Araujo ${ }^{1} \cdot$ Katy Mason ${ }^{2} \oplus$
}

Received: 10 December 2020 / Accepted: 25 October 2021 / Published online: 17 November 2021

(c) The Author(s) 2021

\begin{abstract}
Despite a growing understanding of market infrastructures-the rules and socio-material arrangements that enable agreements on the properties of goods, and the calculation of value, equivalence and exchange-we know little of what lies beneath the arrangements that underpin and are implicated in exchange. The socio-material lens has done much to explain how specific assemblages circulate information and goods, but has done little to explain how different infrastructures configure relations between dispersed market practices. Using the history of the development of the market for market research we show how knowledge-based infrastructures constitute markets as knowledge objects: new expertise emerged through alliances between academia, government, and private actors form a new occupation embodied in specialist agencies that set themselves up in an infrastructural relation to marketing practices. Our conceptualization of markets as knowledge objects extends extant understandings of markets by showing how: (1) extant knowledge-based infrastructures are drawn on to construct new markets; (2) infrastructural relations emerge between different markets to constitute multiple systems of provision and demand, leading to an increasingly valuable knowledge infrastructure; and (3) organized practices in one market are often heavily reliant on connections to other markets, including knowledge-based infrastructures such as market research services.
\end{abstract}

Keywords Markets $\cdot$ Infrastructures $\cdot$ Market research as a knowledge-based infrastructure

\section{Introduction}

While the market studies discipline recognizes the sociomaterial structure of markets as dynamic and always in-themaking (Kjellberg \& Helgesson, 2006), little has been done to explore the making of what lies beneath these emergent structures, or to explain how these infra-structures are drawn on to construct new markets and new worlds (Kjellberg et al., 2019). Put differently, we know little of how infrastructure, and infrastructural work contribute to the iterative and distributed governance of markets (Cochoy et al., 2016). Using the market for market research services, this paper illustrates how a particular form of infrastructure-a knowledge-based infrastructure-is formed by the emergence of novel forms of expertise that become gradually

\section{Katy Mason}

k.j.mason@lancaster.ac.uk

Luis Araujo

luis.araujo@manchester.ac.uk

1 Alliance Manchester Business School, Manchester, UK

2 Lancaster University Management School, Lancaster, UK sedimented into market practices, pervading the private and public sectors.

We claim that knowledge-based infrastructures constitute markets as knowledge objects by accumulating a highly structured and interrelated set of data, information, knowledge, and expertise concerned with and useful to the organization of market exchanges. Furthermore, this knowledge-based infrastructure is part of what Scott (1998) called the construction of sight through the distantiated representation and organization of modes of intervention in socio-economic life. Thus, the knowledge infrastructure that serves markets has benefited from and contributed to how states developed forms of classification, information, and governance of citizens.

We start from the notion that formal markets rely on sociomaterial infrastructures that organize agreements on the properties of goods, calculative spaces, equivalences of value, and other common operating principles (Callon \& Muniesa, 2005; Thévenot, 2015). The establishment of these principles and spaces of equivalence is the product of significant investments in classification, valuation, calculation, standards, measurement devices that underpin the regular, structured and patterned exchanges that constitute markets (Lee et al., 2018). 
Whereas market infrastructures are often transparent, contemporary markets can also feature complex socio-material infrastructures that are opaque to outsiders or even market participants. For example, Özden-Schilling's (2016) (study of deregulated electricity markets shows how exchanges depend on electronic communication networks connecting buyers and sellers, and distributed forms of expertise to operate and maintain those networks. Pardo-Guerra (2019) highlights how global financial markets depend on the range of critical infrastructural work upon which market trades depend.

In this paper, we shift our attention away from the socio-material infrastructures directly implicated in market exchange and explore their more opaque counterparts that turn markets into knowledge objects. Our aim is to understand how knowledge-based infrastructures that are physically and temporally distantiated from market exchanges, construct knowledge that is "....inscribed in and constitutive of economic objects as relevant to the practical activities of economic agents" (Knorr-Cetina \& Preda, 2001: 31). We examine how these knowledge-based infrastructures become markets in their own right, producing and selling information, knowledge and expert advice to downstream markets, involving both the private and public sectors.

We use the example of market research services to show how infrastructural relations between these services and their client markets were established and developed, and how they came to underpin and sustain a wide range of practices beyond markets. Put differently, we ask: what underpinned the emergence of market research professional services and how did market research establish itself as a wide-ranging knowledge infrastructure in its own right?

We make three conceptual contributions to the literature on market infrastructures. First, we show that extant knowledge-based infrastructures are drawn on through a range of activities necessary to enroll, assemble and repurpose socio-material structures to enable and sustain the construction of a new market. Secondly, the emergence of infrastructural relations between different markets connects multiple systems of provision and demand, leading to an increasingly valuable knowledge infrastructure. Finally, the notion of infrastructural relations highlights how organized practices in one market are often heavily reliant on connections to other markets, including upstream markets but also knowledge-based infrastructures such as market research.

The paper is structured as follows: first, we provide a brief overview of the literature on market infrastructures. We then draw on historical accounts of the emergence of market research services to illustrate how they established an infrastructural relation to its downstream markets. Finally, we draw lessons from this example and make an argument as to why an infrastructural lens helps us understand market innovation and change.

\section{Conceptualizing market infrastructures}

In this section, we start by providing a brief review of the literature on infrastructures that has emerged over the last two decades (see e.g. Misa et al., 2003; Harvey et al., 2016; Shove \& Trentmann, 2018; Bowker et al., 2019) before we move on to market infrastructures. The term infrastructure, as Bowker et al. (2010: 97) remind us, “...evokes vast sets of collective equipment necessary to human activities, such as buildings, roads, bridges, rail tracks, channels, ports, and communications networks. Beyond bricks, mortar, pipes or wires, infrastructure also encompasses more abstract entities, such as protocols (human and computer), standards, and memory."

Larkin (2013) suggests infrastructures are visible and palpable (e.g. a computer cable plugged into a data point), as well as invisible and difficult to apprehend (e.g. a data point is connected to a larger system, comprising power and data networks, cloud services). These different layers are mobilized to enable a computer to work as part of a larger system. What constitutes the relevant infrastructure at any one moment, depends on the standpoint we choose (e.g. the user, the software specialist, the communications engineer). Thus, what constitutes an infrastructure is a categorizing act, cutting up a network by privileging a particular standpoint. As Star and Ruhleder (1996: 113) remind us, “...infrastructure is a relational concept. It becomes an infrastructure only in relation to organized practices." Thus, rather than asking what an infrastructure is, we should ask when and how something stands in an infrastructural relation to a particular set of practices (Cass et al., 2018).

An infrastructure thus exists when it underpins organized practices. It is always in a dynamic relation with those practices as well as other infrastructures. Secondly, infrastructures are scripted with political, corporate, regulatory, and social expectations about their use, who benefits from their use, who organizes and pays for their maintenance and so on. Finally, although infrastructures are often portrayed as invisible or silent, they invite reflexivity regarding the multiple and diverse uses they can be put to. As Kornberger et al (2017) suggest, infrastructures are generative; they enable the creation of new elements and connections rather than just link up pre-existing and stable elements.

The notion of market infrastructures owes an intellectual debt to this literature. The notion was first invoked by business historians who associate the emergence of formal markets with "... a concentration of transactions at a specific location, such as a marketplace, where infrastructure (e.g., a market hall and surrounding shops, inns, and taverns for refreshment) is provided" (Casson \& Lee, 2011: 14). These infrastructures delimited market spaces where authorities enforced the standardization of weights and measures, adjudicated on disputes, and promoted the transparency and fairness of exchanges. 
The institutional literature follows in the same vein, albeit with an emphasis on the socio-cognitive aspect of infrastructures. As a recent example, Lee et al. (2018) conceive markets as arrangements that enable structured exchanges and routinization requires agreements on items such as product categories, norms, standards, measures, means of payment and so on. It is these conventions that enable regular exchanges, stabilize expectations, enable long term investments and ward off uncertainty. Product categories, for example, play an infrastructural role in generating agreements that enable valuations, comparisons amongst peers and help market actors to position their offerings (cf. Anand \& Peterson, 2000; Durand \& Khaire, 2017; Kennedy, 2005; Navis \& Glynn, 2010; Negro et al., 2010; Rosa et al., 1999). Zhao (2005: 192) went as far as suggesting that classifications are the "...invisible infrastructure and the cognitive basis of the social order."

Categories vary in terms of their form, formalization, and consequences (Schneiberg \& Berk, 2010). They exist in trade directories, specialist publications, government statistics, consumer guides, ranking systems and in the way retail stores configure their space and displays (Azimont \& Araujo, 2007). Thévenot $(1984,2009,2015)$ coined the term 'investment in form' to denote the distributed and sociomaterial character of classifications. Forms are inscribed in statistics, models, standards, and tools, and acquire an infrastructural character when they span a wide range of organizations and markets.

Bowker (2019: 2) brings together a range of disparate elements under the umbrella of thinking infrastructures that “... configure entities (through tracing, tagging); organize knowledge (through search engines); sort things out (through rankings and ratings); govern markets (through calculative practices, including algorithms) and configure preferences (through valuations such as recommender systems)." Kjellberg et al. (2019) in their history of the emergence of barcode scanning in retailing, emphasize the material side of socio-material infrastructures. They define a market infrastructure as a "...materially heterogeneous arrangement that 'silently' supports and structures the consummation of market exchanges" (Kjellberg et al., 2019: 209). In their study, infrastructures emerge when different modules come together (e.g. standards, barcode scanners and printers) to form a large-scale system that gradually comes to underpin a wide range of retailing practices.

Mellet and Beauvisage (2020) propose a novel reading of market infrastructures as knowledge-based, fulfilling three functions. First, they facilitate the production and circulation of market information. Secondly, they are valuation and capitalization infrastructures. They help qualify and establish commensuration between goods, enable the attribution of prices and so on. Finally, they fulfil a coordination function, facilitating the organization of market encounters.
We extend this view of knowledge-based infrastructures to what Knorr-Cetina and Preda (2001:31) called the epistemization of economic transactions, or the way transactions "... rely on and are interstitched with multiple analyses processes and systems in a variety of ways." The work in epistemizing transactions involves the production of distantiated representations of economic realities involving a range of expertise and related occupations such as securities and industry analysts, management consultants, market researchers and so on. The purpose of this work is to produce actionable knowledge, to intervene in the construction of market objects and practices and do so as a profit-making business (Diaz Ruiz \& Holmlund, 2017).

In short, we propose to look at these knowledge-based activities or representational practices as infrastructural to exchange practices (Kjellberg \& Helgesson, 2007). In doing so, we heed the call for a sociology of business knowledge, to examine the proliferation of professional services focused on producing and selling business knowledge (Pollock \& Williams, 2016). Our argument is that these professional services can be best understood as standing in an infrastructural relation with downstream client markets.

The notion of knowledge infrastructures has been deployed in the techno-scientific world. Edwards (2010: 17) defines knowledge infrastructures as “... robust networks of people, artifacts, and institutions that generate, share, and maintain specific knowledge about the human and natural worlds." Similarly, Bowker (2016: 391) sees knowledge infrastructures as "... the network of institutions, people, buildings, and information resources which enable us to turn observation and contemplation of the world into a standardized set of knowledge objects: journal articles and monographs."

Both these definitions emphasize that knowledge systems are based on distributed expertise, shared norms, and practices. We suggest this notion is just as relevant to the social sciences even though the epistemic status of knowledge objects is different than those found in techno-science (Camic et al., 2011). Our knowledge of the economy, for example, depends on the production of statistics on gross domestic products, inflation, the status of labor markets and so on.

Our understanding of markets and business more generally, depends on knowledge infrastructures collecting, analyzing, and trading information, involving both private and public institutions. They relate to what Scott (1998) called the construction of sight through distantiated observation, which underpinned the ability of the state to construct instruments to represent and intervene in nature and society. This conceptualization of market infrastructures marks a significant departure from the functional explanation of market infrastructures as existing to resolve collective action problems (Lee et al., 2018). Rather, it engenders a constructivist 
explanation that assumes market actors construct knowledge, in relation to others in the market, and in other market systems, and incorporate this into their own knowledge schemas and representations of markets and market action.

In the remainder of this paper, we are concerned with the relation between markets and knowledge-based infrastructures. Our overarching research question-how does a knowledge infrastructure lens generate new insights into how organized market practices emerge, evolve, are mediated, and enable sustained market action?-is explored using illustrations from the history of market research services.

\section{Market research as a knowledge infrastructure}

In a seminal paper on the economics of information Stigler (1961) ponders on the self-evident value of information as an economic resource. As he laments, information "...occupies a slum dwelling in the town of economics. Mostly it is ignored: the best technology is assumed to be known: the relation of commodities to consumer preferences is a datum" (ibid: 213). Information-producing industries such as advertising or market research, largely absent in the edifice of neoclassical economics, are treated in the economics of information as institutions that help overcome information asymmetries.

For Berghoff et al. (2012), incomplete and imperfect information is a characteristic of real, operating markets. Marketing is concerned with the provision of information goods, that overcome the asymmetries identified by information economists. In particular, the construction of demand functions requires the collection, analysis, and translation of market information into a form that producers can interpret and act upon. Fitzgerald (1995: 344) sees this as an essential step for producers to "...cater and respond to markets rather than the preconceptions of entrepreneurs, managers and production experts". The production of market information calls for a "...professional, even scientific expertise, as well as special instruments and institutions" (Berghoff et al., 2012: 2).

Market research emerged as a hybrid set of practices, closely tied to the development of corporate marketing practices whilst borrowing, extending, and refining methods, tools and instruments emanating from the social sciences (Nilsson \& Helgesson, 2015). Corporate marketing practices as depicted in marketing management manuals presuppose the existence of a market research infrastructure. Indeed, the role of a market research infrastructure is seldom mentioned except where conventional marketing practices cannot be implemented due to the absence or shortcomings of that infrastructure (cf. Craig \& Douglas, 2001; Jain, 1989; Young \& Javalgi, 2007).
Our purpose in the following sections is to examine selected features of the history of market research to produce an argument about the role of market research as a knowledge-based infrastructure. Our approach follows in the footsteps of Power's (2015) analysis of infrastructures, focusing on the accretion of activities and the formation of knowledge objects, reaching back into the history of their connections with related infrastructures.

To develop and illustrate our argument, we draw on historical texts as well as recent scholarly works on the development of market research (e.g. Igo, 2007; McDonald \& King, 1996; Schwarzkopf, 2016; Stewart, 2009). For the sake of brevity, we restrict the scope of our illustrations from the beginning of the twentieth century to the 1960s, and to developments in the United States and the United Kingdom.

\section{The emergence of market research as a knowledge-based infrastructure}

As Schwarzkopf (2016) suggests, teleological accounts of the emergence of market research have been driven by success stories based on the application of scientific expertise to produce market information. Historians usually take a longer view on how social scientific knowledge migrated downstream to applied domains such as market research. Original social science developments were driven by concerns such as urbanization and poverty as well as the emergence of the modern state, with its efforts to chart territories and population and render them legible (Scott, 1998; Wagner, 2003). Raphael (2012) suggests that embedding the social sciences in Western societies took place through four routes: the emergence of experts as the protagonists of social science programs; the clients and users of social science knowledge; the biography of different tools and techniques such as sampling, polling, interviewing, or classifying; and the history of the institutions that promoted the diffusion of social science knowledge in society.

The emergence of applied social sciences benefited greatly from these early developments. As Schwarzkopf (2016) notes, basic techniques such as sampling techniques, surveys and focus groups, as well as statistical techniques found their way to market research via the work of social reformers and academics. In the UK, the work of Arthur Bowley, a Professor of Economic Statistics at the London School of Economics (LSE), on sampling, followed in the wake of studies promoted by social reformers such as Charles Booth and Seebhom Rowntree. As Osborne and Rose (1999) noted, Bowley may not have been a pioneer in developing representative sampling, but he was certainly one of its most vocal and effective advocates. The advantages of representative samples were obvious: "Because of their scale, samples allowed for the possibility of a degree of detail and exactitude that was not previously imaginable in 
social scientific research; they made for measurement rather than mere surveillance" (Osborne \& Rose, 1999: 384).

A similar pattern occurred in the United States where studies of urban slums and working conditions in the oil industry involved social scientists such as Robert Staughton Lynd and Helen Merrel Lynd. Their 1929 Middletown study proved seminal to the development of opinion and market research (Igo, 2006, 2007). The Middletown study left a strong impression on a Vienna-based group congregated around Paul Lazarsfeld to whom Robert Staughton Lynd became a mentor when Lazarsfeld moved to the US in 1933 (Pooley, 2015). Lazarsfeld arrived in the US armed with two important qualifications: experience in the management of research institutes and an impressive set of quantitative data analysis skills (Fleck, 1998).

Lazarsfeld's previous market studies in Vienna were considered early marketing classics (Fullerton, 1990). Once in the United States, it did not take him long to make a mark in the academic marketing community as well as social research at the Columbia University Institute of Applied Research (Schwarzkopf, 2016). Of particular relevance to market research were two seminal papers that Lazarsfeld $(1935,1937)$ published in the National Marketing Review and its successor, the Journal of Marketing addressing survey questionnaire design.

Our argument is that the notion of a knowledge-based infrastructure helps us describe the connections with extant infrastructures that underpinned research practices that later became central to the formation of a market for market research services. It is to this task we now turn.

\section{Infrastructuring the business of market research}

The migration of academics into market research startups took place in Britain, the US and further afield (Schwarzkopf, 2016). Examples of academics leaving their posts for business include George Gallup and Louis Weld, who went on to offer research services through the opinion polling firm Gallup Robinson Inc. and the advertising agency McCann Erickson.

Many others made indirect contributions through a combination of academic, government and institutional services. Frederick Stephan, Professor of Social Statistics at Princeton, is a case in point. His academic career was interrupted by government service, including working as a consultant to the War Production Board, the War Manpower Commission, and the US Air Force's Evaluation Board during World War II, and the Committee to Evaluate Employment and Unemployment Statistics during the Kennedy administration (New York Times obituary 7th August 1971; Deming, 1971). In between his academic career and government service, Stephan was also a chair of the American Statistical Association and the American Association for Public Opinion Research.
The breadth of Stephan's (1941, 1948, 1957) contributions can be gauged by articles on sampling procedures and surveys in the Journal of the American Statistical Association (1948), the Journal of Marketing (1941) and Public Opinion Quarterly (1957). Individuals such as Stephan were notable not just for their original contributions to develop methods and tools, but for their ability to straddle and connect different disciplinary and professional fields. Their expertise was highly sought after for commercial as well as public policy purposes.

Another notable case of mixing business and scientific expertise is that of the behaviorist J.B. Watson and the advertising agency J. Walter Thompson (JWT). After his exit from academia in 1920, Watson found employment at JWT. His academic credentials and breed of psychology based on prediction and control, resonated with the concerns of the business community at the time as well as the philosophy of JWT's leader, Stanley Resor (Kreshel, 1990).

JWT was an unusual agency and its philosophy closely followed Stanley Resor's quest for professional credibility and a scientific approach to advertising. Resor had established in 1912 his T-Square five basic questions that needed an answer prior to developing an advertising campaign and this approach guided the approach of the agency from 1919 to 1967. The five questions were: (1) What are we selling? (2) To whom are we selling? (3) Where are we selling? (4) When are we selling? and (5) How are we selling? (Nixon, 2013; Schwarzkopf, 2016; West, 1987). Watson's contributions to the practice of advertising are hard to fathom but there is little doubt that Resor saw his role in JWT as fitting with a culture that promoted 'science at the service of business' and 'professionalism' (Kreshel, 1990).

This approach produced a framework to produce advertising copy as well an insatiable appetite for data to answer the five basic questions. JWT's New York Office established a Market Research Department in 1916 and by 1919, felt the need to establish a Planning and Statistical Investigation Department. The London office seems to have followed the American lead in placing its faith in the value of market research. In 1924 a promotional brochure for the London office stated that "...haphazard publicity cannot stand against carefully planned and executed advertising based on market facts accurately compiled" (West, 1987: 204).

As business expanded in the London office in the late 1920s and early 1930s, the proportion of British staff had increased, even though Americans dominated the senior posts. Douglas Saunders was the first British director appointed in 1929 (West, 1987). In 1933, JWT set up a separate market research organization. The main instigator of this move was John Rodgers who had joined the agency in 1931. The name British Market Research Bureau (BMRB) was designed to get away from the American sounding JWT and to sound British, authoritative, or even academic (Downham, 1995). 
The first Board of BMRB included three directors, two of whom, John Rodgers and Bedford Attwood, became central figures in subsequent developments. Rodgers eventually became Chairman in 1935 and retained that position until 1955. Attwood was another graduate of the London School of Economics and an accomplished statistician. He was on the Board of BMRB until 1944 and in 1947 founded another research company, Attwood Statistics (Downham, 1995). By the 1950s, BMRB employed over 150 people including an array of research executives with degrees in social science subjects and statistics, making use of official statistics as well as data produced by the agency (Nixon, 2013).

The development of market research also benefited from what Igo (2006) called the commingling of marketing with various forms of opinion research. Two central figures in American opinion research, George Gallup and Elmo Roper, arrived at the area via a business route and considered themselves marketing consultants as much as pollsters (Igo, 2006, 2007). Opinion research was a business that marketed its services to clients such as newspapers. The joining up of marketing and opinion research was evident in the way these firms conducted their business, mixing the same methods, assistants and even respondents in the same operation. Market research and opinion surveys were regarded by agencies and some of their clients as effectively indistinguishable (Igo, 2006).

In Britain, the cross-over between market and opinion research can be traced back to a social research project called Mass Observation, founded in 1937 (Moran, 2008). The multidisciplinary and idiosyncratic character of this project meant it was soon competing as well as collaborating with market research and opinion polling firms. Founding figures of the Market Research Society had strong connections to advertising, market, and opinion research firms. Moran (2008) cites the example of Mark Abrams as an example of the intersection of market and opinion research in the post war period. Abrams' career included stints at the advertising agency London Press Exchange prior to World War II, followed by survey work during wartime, and the founding of Research Services Limited, a firm that combined market, opinion, and political work.

In short, an infrastructural analysis reveals how a market for market research services was formed by its relations to knowledge infrastructures operating in other market (e.g. firms buying advertising services, polling, and opinion services) and non-market (academia, government) domains. This opening-up of new market opportunities through extended infrastructural relations, connecting multiple systems of provision and demand, render visible how fragmented knowledge infrastructures became increasingly related and valuable to a range of client markets.

\section{Mediating knowledge infrastructures and market infrastructuring}

An infrastructural lens is also helpful to trace the links between the growth state-making activities, evident from the late nineteenth century onwards, and the emergence of market research. As Asad (1994) and Scott (1998) noted, state-making involved devising administrative techniques to deal with changing populations and their needs (e.g. public health, poverty, education). Social surveys and statistics thus became integral to the representation of different facets of socio-economic life and the ability of nation-states to govern themselves as autonomous political entities (Desrosières, 2002). Scott (1998) suggests that the state's ability to see depends on forms of classification and calculation infrastructures that bring aspects of social reality into light, making them legible and susceptible to measurement.

The early development of markets relied heavily on the classification drive that characterized state-making in this period. As Asad (1994) suggests, three interrelated developments internal and external to state practices, were important in advancing statistical representations: social security legislation, consumer goods markets, and market and polling research. All these developments produced a knowledge infrastructure fit for representing and intervening in a wide range of domains.

Early developments of market research helped to promote as well as benefited from these developments. In the US, Lockley (1950) mentions the early role of the Department of Commerce in supplying market information to businesses and lays the groundwork for studies such as distribution surveys and distribution cost analysis. As Lockley (1950: 736) acknowledged: "With the collection of economic and market data on a large scale by the government, market research flourished."

Stapleford's (2007) study of Consumer Expenditure by New Deal agencies in the 1930s shows how businesspeople became involved in the process and the outcome favored market researchers more than the economic planning aims of the New Deal. Whereas the aim of the survey was to forecast aggregate demand, market researchers seized upon a trove of information on income distribution and demand in specific regions. Alderson (1940: 1) summarized the rewards of the Consumer Expenditure Survey as follows:

Where does the market analyst go for his knowledge of consumer markets? Often, he must go to consumers, or at least to a sample group of them, for such information as they are willing to give about their incomes and their habits of spending and saving. Fortunate is he, indeed, when a public agency such as a branch of the Federal Government undertakes to gather such information for him on a more com- 
prehensive scale than most marketing organizations could afford to do it for themselves.

The state did not just sponsor large-scale studies that were of direct interest to marketing practices. They were also active in undertaking market research on their own or in cooperation with others. Engle (1940), who had moved from President of the American Marketing Association in 1939 to Assistant Director of the Bureau of Domestic and Foreign Commerce at the time of publication, published a survey of commissioned market research projects between 1935 and 1939. Of the 676 projects surveyed, University agencies undertook $57 \%$ of the projects, government agencies 30\%, with business firms accounting for $11 \%$. Another $2.5 \%$ of projects involved University and government agencies.

Schwarzkopf (2012) paints a similar picture for Britain. Benefiting from the crossover of tools such as surveys and statistics, market researchers became active in both commercial and government-sponsored activities. As in the US, market researchers benefited from Social Surveys and running surveys on food consumption and expenditure. From 1941, the Social Survey unit run by Louis Moss, with prior associations to polling and public opinion agencies, relied on methods such as random sampling, survey questionnaires and household panels. All these methods became routinely utilized by commercial market research agencies. Indeed, Social Survey work was regularly outsourced to prominent market research and advertising agencies.

The Market Research Society founded in 1946 by twenty-three individuals, mostly with connections to the London School of Economics, with strong representation from governmental and public organizations (McDonald \& King, 1996; Moran, 2008). Schwarzkopf (2012: 187) concludes that: "Looking at the case of pre-war and wartime surveys, it is abundantly clear that market and consumer research was not a birth child of the marketplace alone, but instead emerged as a set of instruments within the public sector and was often driven by governmental departments."

In sum, an examination of infrastructural relations reveals how organized practices in one domain relied on and fed into connections to other domains. In particular, the state played a range of roles that fostered the emergence of market research as a professional service business. It played a background role in providing the official statistics and nurturing the expertise that underpinned market research. It also came into the foreground as a major client of market research services and a supporter of its professionalization and regulation. Lastly, an infrastructural lens recognizes the circuits of learning at play across multiple infrastructures, with changes in one infrastructure feeding back and affecting others in a chain of re-actions and re-forms.

\section{Market infrastructuring}

In the above account of the early history of market research, and its relations with opinion and political surveys, we presented a selection of illustrations to show how an infrastructural lens helps reveal the complex genealogy of market research services. We have shown how market researchers drew on extant infrastructures from non-market (social sciences, academia, government) as well market domains (opinion and polling service markets) to establish the area as a substrate to a wide range of practices. The trajectory we portrayed is neither teleological nor functionalist. Rather, our narrative shows how a multiplicity of activities, expertise and materials at hand were brought together to build market research services as a knowledge-based market infrastructure.

The notion of expertise and materials at hand is an important one for those seeking to understand and intervene in markets (Mason \& Araujo, 2021). What is at hand, in our market research illustration, is knowledge of methods, tools and techniques. This knowledge is held together and progressed by infrastructures. Knowledge infrastructures are important because, as Edwards (2010: 19) explains: "Without the infrastructure ...knowledge can decay or even disappear. Build up a knowledge infrastructure, maintain it well, and you get stable, reliable, widely shared understanding." Knowledge infrastructures ensure that various forms of knowledge and knowing are at hand for service providers and their clients across a wide range of markets. We represent these infrastructural relations in Fig. 1 and conceptualize market infrastructuring as the work of bringing to hand the assemblages of expertise and materials to generate innovative market infrastructures that develop and sustain market exchanges downstream.

We make three key observations to help us better understand what it means to do market infrastructuring work:

01 A range of activities are necessary to enroll, assemble, and build a knowledge-based infrastructure that enables and sustains a market for professional services such as market research.

The illustrations we presented earlier shed light on the work done by individuals and their organizations to enroll the infrastructures of social science, academia, and government, as well as produce, make use of and validate research practices and instruments, survey instruments, questionnaires, analytical and statistical techniques. These practices travelled from universities through the experts that carried them and the start-up agencies they founded, or helped to found, into diverse domains such as corporations, government departments, public bodies, research institutes and polling organizations. 


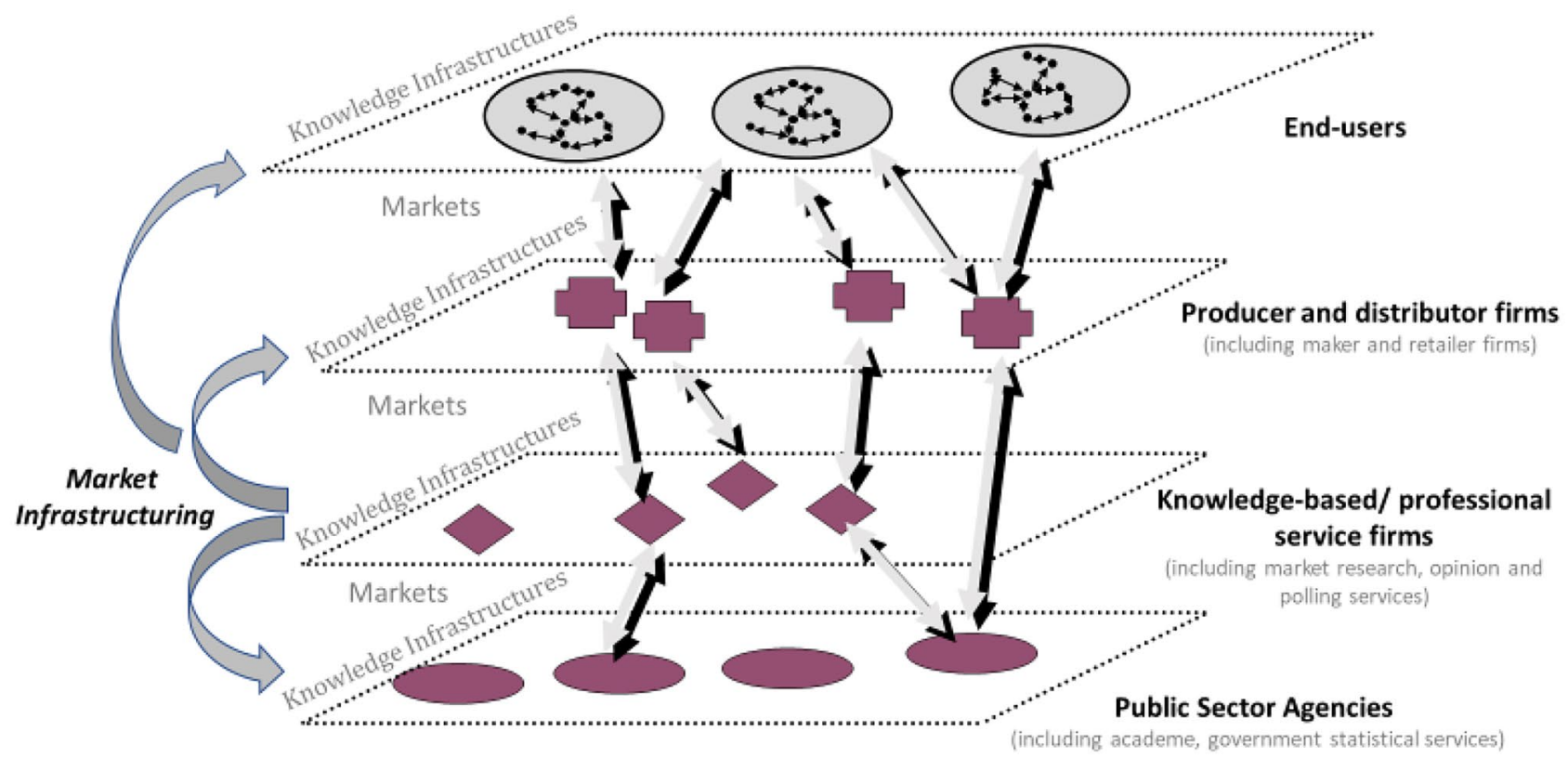

Fig. 1 Market infrastructuring: the work of selecting and assembling aspects from extant knowledge infrastructures to construct and sustain a market

When clients framed research problems, key actors worked to address them, mobilizing different aspects of extant knowledge infrastructures. For example, when market research agencies struggled to gain the trust of a suspicious public in post-war Britain, the UK Market Research Society took upon itself the task of promoting market research as both scientific and ethical through activities such as drawing up a code of practice, sponsoring publications about market research, and acting as a representative of the emerging profession (Moran, 2008). Prominent industry figures and founder members of the society appeared in the national press extolling the democratic value and credentials of market research and opinion surveys. Similarly, in the US, pioneers such as George Gallup and Elmer Roper busily promoted opinion research as representing the people's voice in the corridors of power, and market research as the means to restore the link between manufacturers and consumers in a mass market era (Igo, 2006).

Our second observation is:

O2 Infrastructural relations between different markets connect multiple systems of provision and demand leading to increasingly valuable but fragmented knowledge infrastructures.

This observation has wide-ranging implications for understanding market infrastructuring. The emerging market research conventions were the result of investments of boundary spanning individuals such as JB Watson, Paul Lazarsfeld and Fredrick Stephan in the US, or Arthur Bowley in the UK, made possible because they crossed from academia to government and the private sector, from social and opinion survey research to market and political research. These norms circulated and were further developed through professional associations (Fligstein, 2001). These individuals acted as what Abbott (2005) called hinges, enabling productive alliances between individuals located in different socio-professional ecologies. These hinges were critical to market infrastructuring work, with felicitous consequences for the emergence of market research services.

Our final observation is:

O3 Infrastructural relations show how organized practices in one market rely on connections to other markets and to non-market domains.

This suggests that the work done to build knowledge infrastructures to represent populations and territories for the state played an important role in the early development of market research and created a web of interdependencies that persists to this day. A recent example from the UK provides an apt illustration. A response by the UK Market Research Society (MRS) Census \& Geodemographics Group to the wide-ranging consultation about the UK 2021 Census stated:

Questions included in this topic were used in the 2011 Census to derive Approximate Social Grade, and we will continue to need this classification on the 2021 Census. Social Grade is the primary social classification used in Advertising, Market Research and Media 
Research; literally millions of pounds of advertising expenditures are allocated based on it. Approximate Social Grade from the census is the only source of social grade profiles for small areas.

If the emergence of market research relied on state-making, the dawn of digital economies partially reversed this relation, with states profiting from the vast amounts of market data collected, analyzed, packaged, and sold by private firms. As Scott (1998) remarked, seeing like a state relied on simplifications, control, and predictability. Conventional market research relies on similar premises: extract individual consumer insights from data about their preferences and motivations; subdivide them into segments; choose which segments to target; design marketing mixes to reach the selected targets (Darmody \& Zwick, 2020).

By contrast, digital economies work with a multitude of footprints across a variety of media (e.g. social media platforms, websites, payment systems, geolocation data) rather than data about whole individuals. As Cluley and Brown (2015: 138) put it: "Markets are, as a result, not broken up into individual consumers but increasingly constructed out of components extracted from anonymous and aggregated consumer data".

The power of large companies of the digital age such as Google, Amazon or Facebook, rests on a different knowledge infrastructure, based on expertise such as search and data analytics which allowed them to carve strong positions in the digital advertising market (Lammi \& Pantzar, 2019; Mellet \& Beauvisage, 2020). The skills that underpin this infrastructure were primarily developed for commercial markets but have quickly spread to the public sector. We also witness the widespread mashing of data sets culled from both market and public sector sources (e.g. credit scoring, health data) to impinge upon decision-making in the public sector.

Put differently, in the digital age states have increasingly learned how to see like markets (Fourcade \& Healy, 2017). The citizen-consumer of the twentieth century has been gradually replaced by a data citizenship with the citizenconsumer becoming a data producer as well as a source of value creation for private and public gain (Lammi \& Pantzar, 2019).

One example of data citizenship is citizen scoring in the UK defined as "...typical practices of data analytics in public services to do with the categorization and segmentation, and sometimes rating and ranking, of populations according to a variety of interoperable data sets, with the goal of allocating resources and services accordingly" (Dencik et al., 2019: 3). Citizen scoring is thus built on the same principles that led consumer credit scoring to become the information infrastructure for a range of consumer credit and lending markets in the US and elsewhere (Poon, 2009). A survey of UK public sector applications uncovered a wide range of uses, involving public services (e.g. policing, social care) and local government authorities. Some of these applications were based on aggregate judgments to identify trends (e.g. crime maps). Others rely on identifying or ranking types of risks (e.g. child welfare) for specific populations or individuals. In short, market infrastructuring work establishes figure-ground relations that tend to evolve over time depending on how methods, skills, techniques, and resources come together in configurations that are susceptible to be overturned by changes in these elements or their linkages.

\section{Conclusions}

This paper has used the notion of knowledge-based infrastructures as a means of understanding how market practices have turned into knowledge objects or become epistemized, to revisit Knorr-Cetina and Preda's (2001) terminology. Using market research services as an example, we sought to illustrate how the construction of sight in states and markets share a common ancestry and have had an ever-evolving relation of mutual dependence. Our reading of infrastructures suggests market innovations may depend on the abilities of expert actors to identify, mobilize, and draw on extant infrastructures in pursuit of their own ends by connecting them to extant market infrastructures.

Our illustrative example “...renders visible, knowable and thinkable complex patterns of human interaction in and out of the market, in feedback loops of learning, reformatting, and redoing (Bowker et al., 2019: 1). Methodologies, tools, and techniques are built, adopted, or modified, marketing practices transformed and ways of representing markets revised. While our illustrations do not claim to be systematic, we suggest they reveal the potential for an infrastructure lens to uncover socio-material arrangements that underpin representational market practices.

Our argument can be summarized in three points: (1) a range of activities are necessary to enroll, assemble and repurpose social-material structures to enable and sustain the construction of markets; (2) the emergence of infrastructural relations between different markets connects multiple systems of provision and demand leading to an increasingly valuable knowledge infrastructure; and (3) the notion of infrastructural relations highlights how organized practices in one market are often heavily reliant on connections to other markets, including upstream markets but also knowledge-based infrastructures such as market research.

We extract four implications from our arguments. First, an infrastructure lens directs the researcher's attention to the actions, expertise and materials at hand; an exploration of how these materials come to hand, are brought together by disparate and seemingly unrelated expert agencies. Our illustrative 
example shows that this 'coming to hand' is sometimes purposive and sometimes accidental, producing and performing new versions of markets. This happens when expert individuals operating at the boundaries of markets forge novel connections to open up new professional and business opportunities. These, in turn, may serve as infrastructures for other markets, connecting to extant institutionalized practices as well as creating new ones (see Kjellberg et al., 2019).

To date, the notion of knowledge infrastructures has been largely neglected as a foundation for representing and intervening in markets. We suggest that expertise, as a key element in the cannon of infrastructure studies, offers a valuable domain to inquire into the emergence of new markets as well as the role of market infrastructures in spawning market innovations.

Second, the conceptualization of markets as standing in an infrastructural relation to other markets focuses attention on how infrastructures underpin multiple markets, providing a useful vocabulary to describe how systems of provision and demand are linked, and how particular markets become connected through these relations. To date, the literature has focused on understanding the emergence of a single market (cf. Palo et al., 2020) or the overlaps that emerge between adjacent markets (cf. Kjellberg \& Olson, 2017; Pflueger et al., 2019) but have seldom considered how infrastructures grow to support organized practices across multiple markets.

Thirdly, an infrastructural lens makes visible seemingly unrelated issues such as the regulation of markets based on the balance between public and corporate interests, policy interventions in markets and the provision of public goods. A few recent studies on how health policies influence the development of healthcare markets (cf. Mason \& Araujo, 2021), or how media systems play a role in food markets (cf. Hopkinson, 2017), made inroads in this domain, but few studies have attempted to capture the multiple systems that construct and perform markets. An infrastructure lens provides a theoretical vocabulary to explore this theme and encourages research that examines how multiple markets are connected by related infrastructures.

Finally, the notion of knowledge infrastructures holds promise to study what constitutes marketing expertise, how it is organized, bought and sold as a professional service. Studies such as Diaz Ruiz (2013), Diaz Ruiz and Holmlund (2017), Nilsson (2019, 2021) Jacobi et al (2015) and Hafezieh (2019) on market research, advertising and digital marketing services provide examples of how different aspects of marketing expertise are constructed and enacted in provider-client relationships. These studies provide useful templates to examine the epistemological status of marketing expertise but also how that expertise stands in an infrastructural relation with marketing practices cutting across a variety of sectors, both private and public.
In sum, we call for studies that make use of the conceptual tools developed and discussed by infrastructure scholars. We hope that these insights inspire others to pursue empirical work, exploring the opportunities to see market innovation more broadly through the prism of what we have called market infrastructuring.

Acknowledgements The authors would like to acknowledge the invaluabe contributions of the Guest Editors and the anonymous reviewers to the development of this paper. Their comments and observations throughout the review process were always insightful and constructive. We are deeply grateful.

\section{Declarations}

Conflict of interest statement The authors declare that they have no conflict of interest.

Open Access This article is licensed under a Creative Commons Attribution 4.0 International License, which permits use, sharing, adaptation, distribution and reproduction in any medium or format, as long as you give appropriate credit to the original author(s) and the source, provide a link to the Creative Commons licence, and indicate if changes were made. The images or other third party material in this article are included in the article's Creative Commons licence, unless indicated otherwise in a credit line to the material. If material is not included in the article's Creative Commons licence and your intended use is not permitted by statutory regulation or exceeds the permitted use, you will need to obtain permission directly from the copyright holder. To view a copy of this licence, visit http://creativecommons.org/licenses/by/4.0/.

\section{References}

Abbott, A. (2005). Linked Ecologies: States and Universities as Environments for Professions. Sociological Theory, 23(3), 245-274.

Alderson, W. (1940). The Consumer Market-Income, Expenditure, and Savings. Annals of the American Academy of Political and Social Science, 209(1), 1-13.

Anand, N., \& Peterson, R. A. (2000). When market information constitutes fields: Sensemaking of markets in the commercial music industry. Organization Science, 11(3), 270-284.

Asad, T. (1994). Ethnographic representation, statistics and modern power. Social Research, 61(1), 55-88.

Azimont, F., \& Araujo, L. (2007). Category reviews as market-shaping events. Industrial Marketing Management, 36(7), 849-860.

Berghoff, H., Scranton, P., \& Spiekermann, U. (2012). The Origins of Marketing and Market Research. Information, Institutions, and Markets. The Rise of Marketing and Market Research. H. Berghoff, P. Scranton and U. Spiekermann. London, Palgrave Macmillan: 1-26.

Bowker, G. C. (2016). How knowledge infrastructures learn. In P. Harvey, C. B. Jensen, \& A. Morita (Eds.), Infrastructures and social complexity: A companion (pp. 391-403). Routledge.

Bowker, G. C., Baker, K., Millerand, F., \& Ribes, D. (2010). Toward Information Infrastructure Studies: Ways of Knowing in a Networked Environment. In J. Hunsinger, L. Klastrup, \& M. Allen (Eds.), International Handbook of Internet Research (pp. 97-117). Dordrecht, Springer.

Bowker, G. C., Elyachar, J., Kornberger, M., Mennicken, A., Miller, P., Nucho, J. R., \& Pollock, N. (2019). Introduction to Thinking Infrastructures. Kornberger, M. Bowker, G. C., Elyachar, J., 
Mennicken, A., Miller, P., Nucho, J. R. and N. Pollock. Bingley, Emerald., 62, 1-13.

Callon, M., \& Muniesa, F. (2005). Peripheral Vision: Economic Markets as Calculative Collective Devices. Organization Studies, 26(8), 1229-1250.

Camic, C., Gross, N., \& Lamont, M., Eds. (2011). Social Knowledge in the Making Chicago, University of Chicago Press.

Cass, N., Schwanen, T., \& Shove, E. (2018). Infrastructures, intersections and societal transformations. Technological Forecasting and Social Change, 137, 160-167.

Casson, M., \& Lee, J. S. (2011). The Origin and Development of Markets: A Business History Perspective. Business History Review, 85(01), 9-37.

Cluley, R., \& Brown, S. D. (2015). The dividualised consumer: Sketching the new mask of the consumer. Journal of Marketing Management, 31(1-2), 107-122.

Cochoy, F., Trompette, P., \& Araujo, L. (2016). From market agencements to market agencing: An introduction. Consumption Markets \& Culture, 19(1), 3-16.

Craig, C. S., \& Douglas, S. P. (2001). Conducting international marketing research in the twenty-first century. International Marketing Review, 18(1), 80-90.

Darmody, A., \& Zwick, D. (2020). Manipulate to empower: Hyperrelevance and the contradictions of marketing in the age of surveillance capitalism. Big Data \& Society, 7(1), 1-12.

Deming, W. E. (1971). In Memoriam: Frederick Franklin Stephan 1903-1971. The American Statistician, 25(4), 47-48.

Dencik, L., Redden J, Hintz, A., \& Warne, H. (2019). The 'golden view': data-driven governance in the scoring society. Internet Policy Review 8(2): 1-24 (available at http://hdl.handle.net/ 10419/214080, accessed 17th October 2021)

Desrosières, A. (2002). Three Studies on the History of Sampling Surveys: Norway, Russia-USSR, United States. Science in Context, 15(3), 377-383.

Diaz Ruiz, C. (2013). Assembling market representations. Marketing Theory, 13(3), 245-261.

Diaz Ruiz, C., \& Holmlund, M. (2017). Actionable marketing knowledge: A close reading of representation, knowledge and action in market research. Industrial Marketing Management, 66, $172-180$.

Downham, J. (1995). BMRB International: 1993-1995 - The First Sixty Years. BMRB.

Durand, R., \& Khaire, M. (2017). Where do market categories come from and how? Distinguishing category creation from category emergence. Journal of Management, 43(1), 87-110.

Edwards, P. N. (2010). A vast machine: Computer models, climate data, and the politics of global warming. MA, MIT Press.

Engle, N. (1940). Gaps in marketing research. Journal of Marketing 4(4 part_1): 345-353.

Fitzgerald, R. (1995). Rowntree and the Marketing Revolution, 1862-1969. Cambridge University Press.

Fleck, C. (1998). The choice between market research and sociography, or: What happened to Lazarsfeld in the United States? Paul Lazarsfeld (1901-1976): la Sociologie de Vienne à New York. J. Lautman and B.-P. Lécuyer. Paris, Éditions l'Harmattan.

Fligstein, N. (2001). The Architecture of Markets. Princeton, NJ., Princeton University Press.

Fourcade, M., \& Healy, K. (2017). Seeing like a market. SocioEconomic Review, 15(1), 9-29.

Fullerton, R. A. (1990). The Art of Marketing Research: Selections from Paul F. Lazarsfeld's Shoe Buying in Zurich. Journal of the Academy of Marketing Science, 18(4), 319-327.

Hafezieh, N. (2019). Understanding Organizational Digital Transformation. Towards a Theory of Search, University of Edinburgh. Unpublished $\mathrm{PhD}$ thesis.
Harvey, P., Jensen, C. B., \& Morita, A. (2016). Introduction. Infrastructural complications. Infrastructures and Social Complexity: A Companion. P. Harvey, C. B. Jensen and A. Morita. London, Routledge. 1-21.

Hopkinson, G. C. (2017). Making a market for male dairy calves: Alternative and mainstream relationality. Journal of Marketing Management, 33(7-8), 556-579.

Igo, S. E. (2006). "A gold mine and a tool for democracy": George Gallup, Elmo Roper, and the business of scientific polling, 19351955. Journal of the History of the Behavioral Sciences, 42(2), 109-134.

Igo, S. E. (2007). The Averaged American. Cambridge, MA, Harvard University Press.

Jain, S. C. (1989). Standardization of International Marketing Strategy: Some Research Hypotheses. Journal of Marketing, 53(1), 70-79.

Jacobi, E. S., Freund, J., \& Araujo, L. (2015). 'Is there a gap in the market, and is there a market in the gap?' How advertising planning performs markets. Journal of Marketing Management, 31(1-2), 37-61.

Kennedy, M. T. (2005). Behind the one-way mirror: Refraction in the construction of product market categories. Poetics, 33(3-4), 201-226.

Kjellberg, H., \& Helgesson, C. -F. (2006). Multiple versions of markets: Multiplicity and performativity in market practice. Industrial Marketing Management, 35(7), 839-855.

Kjellberg, H., \& Helgesson, C. -F. (2007). On the nature of markets and their practices. Marketing Theory, 7(2), 137-162.

Kjellberg, H., \& Olson, D. (2017). Joint markets: How adjacent markets influence the formation of regulated markets. Marketing Theory, $17(1), 95-123$.

Kjellberg, H., Hagberg, J., \& Cochoy, F. (2019). Thinking Market Infrastructure: Barcode Scanning in the US Grocery Retail Sector, 1967-2010. Thinking Infrastructures. Kornberger, M. Bowker, G. C., Elyachar, J., Mennicken, A., Miller, P., Nucho, J. R. and N. Pollock. Bingley, Emerald., 62, 207-232.

Cetina, K. K., \& Preda, A. (2001). The epistemization of economic transactions. Current Sociology, 49(4), 27-44.

Kornberger, M., Pflueger, D., \& Mouritsen, J. (2017). Evaluative infrastructures: Accounting for platform organization. Accounting, Organizations and Society, 60, 79-95.

Kreshel, P. J. (1990). John B. Watson at J. Walter Thompson: The legitimation of "science" in advertising. Journal of Advertising, 19(2), 49-59.

Lammi, M., \& Pantzar, M. (2019). The data economy: How technological change has altered the role of the citizen-consumer. Technology in Society 59: 101157.

Larkin, B. (2013). The politics and poetics of infrastructure. Annual Review of Anthropology, 42, 327-343.

Lazarsfeld, P. F. (1935). The art of asking WHY in marketing research: Three principles underlying the formulation of questionnaires. National Marketing Review, 1, 26-38.

Lazarsfeld, P. F. (1937). The use of detailed interviews in market research. Journal of Marketing, 2(1), 3-8.

Lee, B. H., Struben, J. \& Bingham, C.B. (2018). Collective action and market formation: An integrative framework. Strategic Management Journal, 39(1), 242-266.

Lockley, L. C. (1950). Notes on the history of marketing research. Journal of Marketing, 14(5), 733-736.

Mason, K., \& Araujo, L. (2021). Implementing Marketization in Public Healthcare Systems: Performing Reform in the English National Health Service. British Journal of Management, 32, 473-493.

Mellet, K., \& Beauvisage, T. (2020). Cookie monsters. Anatomy of a digital market infrastructure. Consumption Markets \& Culture, 23(2), 110-129.

Misa, T. J., Brey, T. \& Feenberg, A. (Eds.). (2003). Modernity and Technology. Cambridge. 
Moran, J. (2008). Mass-observation, market research, and the birth of the focus group, 1937-1997. Journal of British Studies, 47(4), $827-851$.

McDonald, C., \& King, S. (1996). Sampling the Universe: Growth, Development and Influence of Market Research in Britain Since 1945. NTC Publications.

Navis, C., \& Glynn, M. A. (2010). How New Market Categories Emerge: Temporal Dynamics of Legitimacy, Identity, and Entrepreneurship in Satellite Radio, 1990-2005. Administrative Science Quarterly, 55(3), 439-471.

Negro, G., Koçak, Ö. \& Hsu, G. (2010). Research on Categories in the Sociology of Organizations. Categories in Markets. Origins and Evolution. G. Hsu, Ö. Koçak and G. Negro. Bradford, Emerald: 3-35.

Nilsson, J. (2019). Know your customer: Client captivation and the epistemics of market research. Marketing Theory, 19(2), 149-168.

Nilsson, J. (2021). Shaping epistemic distance: Producing and withholding knowledge in market research. Journal of Cultural Economy, 14(1), 101-116.

Nilsson, J., \& Helgesson, C. -F. (2015). Epistemologies in the wild: Local knowledge and the notion of performativity. Journal of Marketing Management, 31(1-2), 16-36.

Nixon, S. (2013). Hard Sell: Advertising, Affluence and Transatlantic Relations, c. 1951-1969. Manchester, Manchester University Press.

Osborne, T., \& Rose, N. (1999). Do the social sciences create phenomena?: The example of public opinion research. British Journal of Sociology, 50(3), 367-396.

Özden-Schilling, C. (2016). The infrastructure of markets: From electric power to electronic data. Economic Anthropology, 3(1), $68-80$.

Palo, T., Mason, K., \& Roscoe, P. (2020). Performing a myth to make a market: The construction of the 'magical world' of Santa. Organization Studies, 41(1), 53-75.

Pardo-Guerra, J. P. (2019). Automating finance: Infrastructures, engineers, and the making of electronic markets. Cambridge University Press.

Pflueger, D., Palermo, T., \& Martinez, D. (2019). Thinking Infrastructure and the Organization of Markets: The Creation of a Legal Market for Cannabis in Colorado. Thinking Infrastructures. Kornberger, M. Bowker, G. C., Elyachar, J., Mennicken, A., Miller, P., Nucho, J. R. and N. Pollock. Bingley, Emerald., 62, 233-253.

Pollock, N., \& Williams, R. (2016). How Industry Analysts Shape the Digital Future. Oxford University Press.

Pooley, J. D. (2015). Mnemonic Multiples: The Case of the Columbia Panel Studies. Journal of the History of the Behavioral Sciences, 51(1), 10-30.

Poon, M. (2009). From new deal institutions to capital markets: Commercial consumer risk scores and the making of subprime mortgage finance. Accounting, Organizations and Society, 34(5), 654-674.

Power, M. (2015). How accounting begins: Object formation and the accretion of infrastructure. Accounting, Organizations and Society, 47(November), 43-55.

Raphael, L. (2012). Embedding the Human and Social Sciences in Western Societies, 1880-1980: Reflections on Trends and Methods of Current Research. Engineering Society. The Role of the Human and Social Sciences in Modern Societies, 1880-1980. K. Brückweh, D. Schumann, R. F. Wetzell and B. Ziemann. London, Palgrave Macmillan: 41-56.

Rosa, J. A., Porac, J. F., \& Runser-Spanjol, J. (1999). Sociocognitive dynamics in a product market. Journal of Marketing 63(SISI): 64-77.
Schneiberg, M., \& Berk, G. (2010). From categorical imperative to learning by categories: cost accounting and new categorical practices in American manufacturing, 1900-1930. Categories in markets: Origins and evolution. G. Hsu, Ö. Koçak and G. Negro. Bradford, Emerald: 255-292.

Schwarzkopf, S. (2012). Markets, Consumers and the State: The Uses of Market Research in Government and the Public Sector in Britain, 1925-1955. In H. Berghoff, P. Scranton, \& U. Spiekermann (Eds.), The Rise of Marketing and Market Research (pp. 171192). Macmillan.

Schwarzkopf, S. (2016). In search of the consumer: The history of market research from 1890 to 1960. In D. Jones \& M. Tadajewski (Eds.), The Routledge Companion to Marketing History (pp. 85-108). Routledge.

Scott, J. C. (1998). Seeing Like a State. New Haven, CT., Yale University Press.

Shove, E., \& Trentmann, F. (Eds.). (2018). Infrastructures in practice: The dynamics of demand in networked societies. Routledge.

Stapleford, T. A. (2007). Market Visions: Expenditure Surveys, Market Research, and Economic Planning in the New Deal. Journal of American History, 94(2), 418-444.

Star, S. L., \& Ruhleder, K. (1996). Steps toward an ecology of infrastructure: Design and access for large information spaces. Information Systems Research, 7(1), 111-134.

Stephan, F. F. (1941). Stratification in representative sampling. Journal of Marketing, 6(1), 38-46.

Stephan, F. F. (1948). History of the uses of modern sampling procedures. Journal of the American Statistical Association, 43(241), 12-39.

Stephan, F. F. (1957). Advances in survey methods and measurement techniques. Public Opinion Quarterly, 21(1), 79-90.

Stewart, D. W. (2009). The Evolution of Market Research. In P. Maclaran, M. Saren, B. Stern, \& M. Tadajewski (Eds.), The SAGE Handbook of Marketing Theory (pp. 74-85). Sage.

Stigler, G. J. (1961). The economics of information. Journal of Political Economy, 69(3), 213-225.

Thévenot, L. (1984). Rules and Implements; Investments in Forms. Social Science Information, 23(1), 1-45.

Thévenot, L. (2009). Postscript to the Special Issue: Governing Life by Standards. Social Studies of Science 39(5): 793-813.

Thévenot, L. (2015). Certifying the World: Power Infrastructures and Practices in Economies of Conventional Forms. In P. Aspers \& N. Dodd (Eds.), Re-Imagining Economic Sociology (pp. 195-223). Oxford, Oxford University.

Young, R. B., \& Javalgi, R. G. (2007). International marketing research: A global project management perspective. Business Horizons, 50(2), 113-122.

Wagner, P. (2003). The Uses of Social Science. The Cambridge History of Science: The Modern Social Sciences. D. Ross and T. M. Porter. Cambridge, Cambridge University Press., 7, 535-552.

West, D. C. (1987). From T-Square to T-Plan: The London Office of the J. Walter Thompson Advertising Agency 1919-1970. Business History, 29(2), 199-217.

Zhao, W. (2005). Understanding classifications: Empirical evidence from the American and French wine industries. Poetics, 33(3-4), 179-200.

Publisher's Note Springer Nature remains neutral with regard to jurisdictional claims in published maps and institutional affiliations. 